\title{
Pure dysgerminoma of the ovary: a study of 31 cases
}

\author{
Hasna Salhi ${ }^{1 *}$, Mohamed Ali Ayadi ${ }^{2}$, Imen Bouraoui ${ }^{2}$, Riadh Chargui ${ }^{2}$, Khaled Rahal ${ }^{2}$
}

\author{
${ }^{1}$ Department of Surgical Oncology, Regional Hospital of Siliana, Tunisia \\ ${ }^{2}$ Department of Surgical Oncology, Salah Azaiez Institute, Tunisia
}

Received: 02 June 2021

Revised: 05 July 2021

Accepted: 06 July 2021

\author{
*Correspondence: \\ Dr. Hasna Salhi, \\ E-mail: hasna.salhi@yahoo.fr
}

Copyright: (C) the author(s), publisher and licensee Medip Academy. This is an open-access article distributed under the terms of the Creative Commons Attribution Non-Commercial License, which permits unrestricted non-commercial use, distribution, and reproduction in any medium, provided the original work is properly cited.

\begin{abstract}
Malignant germ cell tumors of the ovary are rare tumors characterized by their heterogeneity and occurring mostly in young women. Dysgerminoma is the most common type of these tumors. This was a retrospective study of 31 patients with pure dysgerminoma of the ovary diagnosed in Salah Azaiez institute of Tunis in Tunisia between 1970 and 2012. The median age was 22 years old. Abdominal pain was the most complaint in $45.1 \%$ of cases. An abdomino-pelvic mass was found in $83.8 \%$ of cases. Surgery was performed in all patients. The median tumoral size was $13.7 \mathrm{~cm}$. Sixty four-point five percent of the patients underwent a conservative surgery. The tumor was classified stage I in $51.6 \%$ of the cases, stage II in $9.7 \%$ of the cases, stage III in $35.5 \%$ of the cases and stage IV in $3.2 \%$ of the cases. Fourteen patients received platinum-based adjuvant chemotherapy, and 10 patients had a radiotherapy. We have noticed 2 cases of recurrence and 2 cases of metastasis. Five-year and ten-year overall survival was $89.4 \%$. Five-year disease free survival was $85.2 \%$ and ten-year disease free survival was $66.3 \%$. Dysgerminomas of the ovary have a good prognosis. The two significant prognostic factors are the stage and the postoperative residual disease.
\end{abstract}

Keywords: Ovary, Germ cell, Tumor, Malignant, Dysgerminoma

\section{INTRODUCTION}

Malignant ovarian germ cell tumors are a rare form of gonadal malignancy that are most prevalent in adolescents and young adults. The most common type of these tumors is dysgerminoma that accounts for $38.2 \%$ of germ cells tumors and for 3 to $5 \%$ of all primary ovarian malignancies. ${ }^{1}$ Dysgerminomas can be pure or mixed being one of several components of a germ cell tumor such as malignant teratoma or choriocarcinoma. ${ }^{2}$ It is derived from primordial germ cells of the sexually undifferentiated embryonic gonad and affects predominantly younger women being less than 30 years old. ${ }^{3}$ Nearly $50 \%$ of dysgerminomas occur before the age of 20 but they are rare before the age of $10 .^{3}$

The majority of dysgerminomas are diagnosed at an early stage with unilateral involvement affecting one ovary that's why they respond well to conservative fertilitysparing treatment consisting of unilateral salpingooophorectomy. The oncologic safety of this procedure was confirmed for an early -stage disease and is currently the gold standard. ${ }^{4}$

Ovarian dysgerminomas, like their male counterpart the seminoma, are extremely radio- and chemo sensitive, therefore an excellent prognosis is usually expected and they are generally considered of low-grade malignancy but they may spread. ${ }^{3}$

\section{CASE SERIES}

Thirty-one patients were found to have a pure dysgerminoma of ovary between 1970 and 2012 and are the subject of this study. Patients with dysgerminoma combined with other germ cell tumors were excluded. 
Staging was carried out according to FIGO recommendations. Patients demographic and disease characteristics were summarized using descriptive statistics.

Table 1: Surgical procedures.

\begin{tabular}{|c|c|c|c|c|c|c|}
\hline Case & Age & $\begin{array}{l}\text { FIGO } \\
\text { stage }\end{array}$ & $\begin{array}{l}\text { Surgical procedure } \\
\text { out of ISA }\end{array}$ & Surgical procedure & $\begin{array}{l}\text { Type of } \\
\text { surgery }\end{array}$ & $\begin{array}{l}\text { Residual } \\
\text { tumor }\end{array}$ \\
\hline 1 & 12 & IIIC & $\begin{array}{l}\text { Right } \\
\text { salpingooophorectom } \\
\text { y+ lymphnode biopsy }\end{array}$ & 0 & Conservative & + \\
\hline 2 & 32 & IIIC & $\begin{array}{l}\text { Total hysterectomy+ } \\
\text { salpingoophorectomy }\end{array}$ & 0 & Radical & + \\
\hline 3 & 15 & IIA & $\begin{array}{l}\text { Right } \\
\text { salpingooophorectom } \\
\text { y+ lateroaortic } \\
\text { lymphnode biopsy (-) }\end{array}$ & Complete staging & Radical & - \\
\hline 4 & 22 & IA & 0 & Complete staging & Radical & - \\
\hline 5 & 15 & IA & Left ovariectomy & 0 & Conservative & - \\
\hline 6 & 27 & IIIC & Right ovariectomy & $\begin{array}{l}\text { Right } \\
\text { salpingooophorectomy+omente } \\
\text { ctomy+appendicectomy+ left } \\
\text { oophoropexy + lateroaortic } \\
\text { lymphnode biopsy (+) }\end{array}$ & Conservative & + \\
\hline 7 & 15 & IA & $\begin{array}{l}\text { Left ovariectomy }+ \\
\text { right ovarian biopsy }\end{array}$ & r r & Conservative & - \\
\hline 8 & 21 & IA & Right ovariectomy & $\begin{array}{l}\text { Right salpingoophorectomy } \\
\text { +appendicectomy + left } \\
\text { Ovarian biopsy (-) + lateroaortic } \\
\text { lymphnode biopsy (-) }\end{array}$ & Conservative & - \\
\hline 9 & 60 & IIIC & 0 & $\begin{array}{l}\text { Bilateral } \\
\text { salpingooophorectomy } \\
\text { +omentectomy+ } \\
\text { appendicectomy }\end{array}$ & Radical & + \\
\hline 10 & 32 & IIIC & $\begin{array}{l}\text { Right } \\
\text { salpingooophorectom } \\
\mathrm{y}\end{array}$ & $\begin{array}{l}\text { Left salpingoophorectomy } \\
\text { +omentecomy +resection of a } \\
\text { douglassian nodule }(+)\end{array}$ & Radical & + \\
\hline 11 & 13 & IIIC & $\begin{array}{l}\text { Right } \\
\text { salpingoophorectomy }\end{array}$ & $\begin{array}{l}\text { Omentectomy+appendicet+later } \\
\text { oaortic lymphnode biopsy }(+)+ \\
\text { left ovarian biopsy and left } \\
\text { oophoropexy (-) }\end{array}$ & Conservative & + \\
\hline 12 & 29 & IA & $\begin{array}{l}\text { Left } \\
\text { salpingoophorectomy }\end{array}$ & $\begin{array}{l}\text { Omentectomy+right ovarian } \\
\text { biopsy (-)+ right oophoropexy }\end{array}$ & Conservative & - \\
\hline 13 & 17 & IA & $\begin{array}{l}\text { Right } \\
\text { salpingooophorectom } \\
\text { y }\end{array}$ & 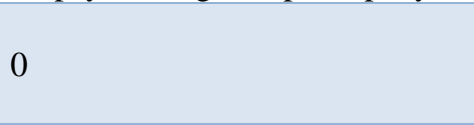 & Conservative & - \\
\hline 14 & 14 & IA & Left ovariectomy & $\begin{array}{l}\text { Conservative staging }+ \\
\text { lateroaortic lymphadenectomy } \\
(-)\end{array}$ & Conservative & - \\
\hline 15 & 31 & IV foie & $\begin{array}{l}\text { Right } \\
\text { salpingoophorectomy } \\
+ \text { omentectomy }\end{array}$ & 0 & Conservative & + \\
\hline 16 & 17 & IIIC & $\begin{array}{l}\text { Ful staging }+ \\
\text { lateroaortic } \\
\text { lymphadenectomy }(+)\end{array}$ & 0 & Radical & - \\
\hline 17 & 17 & IIIC & $\begin{array}{l}\text { Full staging }+ \\
\text { lateroaortic } \\
\text { lymphadectomy }(+)\end{array}$ & 0 & Radical & - \\
\hline
\end{tabular}

Continued. 


\begin{tabular}{|c|c|c|c|c|c|c|}
\hline Case & Age & $\begin{array}{l}\text { FIGO } \\
\text { stage }\end{array}$ & $\begin{array}{l}\text { Surgical procedure } \\
\text { out of ISA }\end{array}$ & Surgical procedure & $\begin{array}{l}\text { Type of } \\
\text { surgery }\end{array}$ & $\begin{array}{l}\text { Residual } \\
\text { tumor }\end{array}$ \\
\hline 18 & 21 & IIIC & $\begin{array}{l}\text { Right } \\
\text { salpingoophorectomy }\end{array}$ & $\begin{array}{l}\text { Conservative staging }+ \\
\text { lateroaortic lymphadectomy }(+)\end{array}$ & Conservative & - \\
\hline 19 & 16 & IC & 0 & Conservative staging & Conservative & - \\
\hline 20 & 41 & IA & $\begin{array}{l}\text { Right } \\
\text { salpingoophorectomy }\end{array}$ & 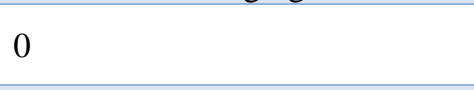 & Conservative & - \\
\hline 21 & 18 & IIIB & 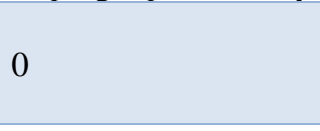 & $\begin{array}{l}\text { Bilateral } \\
\text { salpingoophorectomy+omentect } \\
\text { omy }\end{array}$ & Radical & - \\
\hline 22 & 15 & IA & $\begin{array}{l}\text { Right } \\
\text { salpingoophorectomy }\end{array}$ & 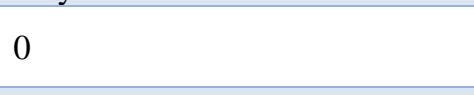 & Conservative & - \\
\hline 23 & 14 & IA & 0 & Right ovariectomy & Conservative & - \\
\hline 24 & 18 & IIA & 0 & $\begin{array}{l}\text { Full staging+ pelvic } \\
\text { lymphadenectomy }\end{array}$ & Radical & - \\
\hline 25 & 11 & IA & $\begin{array}{l}\text { Right } \\
\text { salpingoophorectomy }\end{array}$ & 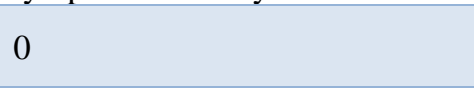 & Conservative & - \\
\hline 26 & 14 & IA & Left cystectomy & $\begin{array}{l}\text { Left } \\
\text { salpingoophorect+oment+appen } \\
\text { dictomy+pelvic and lateroaort } \\
\text { lymphnode biopsy (-) }\end{array}$ & Conservative & - \\
\hline 27 & 33 & IA & 0 & Full staging & Radical & + \\
\hline 28 & 10 & IA & 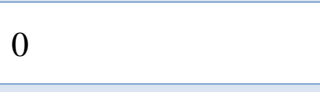 & $\begin{array}{l}\text { Left ovariectomy+ lateroaortic } \\
\text { lymphnode biopsy (-) }\end{array}$ & Conservative & - \\
\hline 29 & 25 & $\mathrm{IC}$ & $\begin{array}{l}\text { Left } \\
\text { salpingoophorectomy }\end{array}$ & 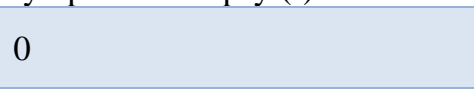 & Conservative & - \\
\hline 30 & 61 & IIA & $\begin{array}{l}\text { Full staging+ pelvic } \\
(-) \text { +lateroaortic } \\
\text { lymphadectomy }(+)\end{array}$ & 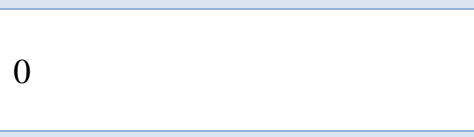 & Radical & + \\
\hline 31 & 18 & $\mathrm{IC}$ & 0 & $\begin{array}{l}\text { Right salpingoophorectomy } \\
\text { +appendicectomy+ pelvic (-) + } \\
\text { lateroaortic } \\
\text { lymphadenectomy(+) }\end{array}$ & Conservative & - \\
\hline
\end{tabular}

Overall survival time was calculated from the time of diagnosis to the date of death or last of follow-up date. Recurrence-free survival time was calculated from the time of diagnosis to the date of recurrence. The overall survival and recurrence free survival curves were constructed using Kaplan-Meier method. Statistical analysis was performed using Statistical package for social sciences (SPSS).

Between 1970 and 2012, 31 patients were diagnosed with pure dysgerminoma of ovary at Salah Azaiez Institute, Tunis, Tunisia. Median age was 22 years-old (ranges from 12 to 60 years old).

Twenty-three patients (76 .6\%) were under 30 years old (FIG1).

From these patients, seven women were married that five of them were multiparous and two patients were menopaused.
Clinical presentation was abdominal-pelvic pain in $45.1 \%$ of cases, an increased abdominal volume in $41.9 \%$ of cases, an abdominal mass in $12.9 \%$ of cases and an amenorrhea in $12.9 \%$ of cases. An acute symptomatology was observed in one case (3.2\%): annex twist. Only one patient was asymptomatic.

On physical examination, most patients had abdominopelvic mass (26 patients) and three patients had ascites. Gynecologic examination was performed for seven patients and it revealed a suspicious mass in digital examination in one patient but the cervix, the vagina and the rectovaginal septum were normal.

Ultrasound examination was performed in 18 patients $(58 \%)$. it showed pelvic mixed solido-cystic mass in 12 cases $(38 \%)$ and ascites in four cases $(12.9 \%)$. Ultrasound examination was normal in 2 patients. CT scan was made for 7 patients and findings were similar to ultrasound 
examination in 6 patients but it showed for the 7 th patient metastatic liver with peritoneal carcinomatosis.

Table 2: Type of chemotherapy (VAB: VinblastineCyclophosphamide- Actinomycin- BleomycinCisplatin/ BEP: Bleomycin- Etoposide-Cisplatin/ EP: Etoposide- Cisplatin).

\begin{tabular}{|llll|} 
Case & $\begin{array}{l}\text { FIGO } \\
\text { stage }\end{array}$ & $\begin{array}{l}\text { Type of } \\
\text { chemotherapy }\end{array}$ & $\begin{array}{l}\text { Number of } \\
\text { cycles }\end{array}$ \\
\hline $\mathbf{1}$ & IIIC & VAB & 6 \\
\hline $\mathbf{2}$ & IIIC & VAB & 6 \\
$\mathbf{3}$ & IA & BEP & 4 \\
\hline $\mathbf{4}$ & IA & BEP & 3 \\
\hline $\mathbf{5}$ & IIIC & BEP & 3 \\
\hline $\mathbf{6}$ & IIIC & BEP & 3 \\
\hline $\mathbf{7}$ & IIIC & BEP & 4 \\
\hline $\mathbf{8}$ & IC & BEP & 3 \\
\hline $\mathbf{9}$ & IA & BEP & 4 \\
\hline $\mathbf{1 0}$ & IA & EP & 3 \\
\hline $\mathbf{1 1}$ & IIA & EP & 6 \\
\hline $\mathbf{1 2}$ & IIIB & EP & 6 \\
\hline $\mathbf{1 3}$ & IC & EP & 6 \\
\hline $\mathbf{1 4}$ & IA & BEP & 5 \\
\hline $\mathbf{1 5}$ & IC & EP & 4 \\
\hline & & & \\
\hline
\end{tabular}

Seven patients had intravenous urography that found 2 cases of mute kidney, 1 case of hydro nephrosis, 1 case of mass syndrome and it was normal in the other case. All patients had chest X-ray that was pathological in one case showing mediastinal adenopathy. Cystoscopy and rectoscopy were performed for two patients and it revealed signs of bladder and colorectal compression.

Tumor markers levels were raised in some patients: Beta HCG was made for 10 patients and it was positive in 5 of them, LDH serum level was markedly elevated in 3 cases. Finally, Ca125 was pathologic in two cases from seven.

The initial management was surgical for all patients with radical intent in 11 patients $(35.5 \%)$ having a complete staging procedure and conservative intent in 20 patients $(64.5 \%)$ having fertility-sparing surgery (Table 1$)$.

Surgery was optimal in 22 patients $(70.96 \%)$ of which four were at stage III. Five patients with advanced stage underwent fertility-sparing surgery. Among them, 4 were single with stage IIIC dysgerminomas and 1 had metastatic liver.

A 60 years old woman diagnosed with stage IIIC dysgerminoma had a big douglassian nodule and detachment between the bladder and the uterus was so difficult that why hysterectomy was not possible. She underwent bilateral salpingoophorectomy with omentectomy and appendicectomy. Then, she had hysterectomy after chemotherapy.
A 32 year-old woman diagnosed with stage IIIC dysgerminoma on right salpingoophorectomy performed out of our institute. She had internal iliac lymphnodes blocking the pelvis with a douglassian nodule and a normal uterus so that, surgical procedure was resumed at left salpingoophorectomy with omentectomy and resection of the douglassian nodule. She underwent hysterectomy after chemotherapy.

Pelvic lymphnode sampling was performed in 7 patients and it was positive in 3 cases.

Seven patients underwent pelvic and lateroaoartic lymphadenectomy that was positive in 5 cases. Therefore, the rate of lymph node involvement was $51.1 \%$ in these cases of dysgerminomas.

Twelve patients $(38.7 \%)$ were classified as stage IA and they underwent conservative surgery. Three of them $(9.6 \%)$ had contralateral ovarian biopsy that was negative in all cases.

The median tumor size was $13.7 \mathrm{~cm}$ (ranges from 8 to 30 $\mathrm{cm})$. Tumor size was upper than $10 \mathrm{~cm}$ in 29 cases $(93.5 \%)$ and upper than $20 \mathrm{~cm}$ in 9 cases $(29 \%)$.

The tumor was on the right side in 16 patients $(51.6 \%)$, on the left side in 6 patients $(19.3 \%)$ and bilateral in 9 patients (29.1\%).

According the FIGO stage: sixteen patients were classified stage I $(51.6 \%)$, three patients stage II $(9.7 \%)$, eleven patients stage III (35.5\%) and one patient stage IV (3.2\%).

Adjuvant chemotherapy was indicated in 15 patients (Table 2). It was performed in 5 cases $(16.1 \%)$ with FIGO stage IA having a tumor size that ranged from 15 to $18 \mathrm{~cm}$.

Adjuvant radiotherapy was indicated in 10 patients (32.2\%) with a dose that ranged between 16 and $55 \mathrm{~Gy}$. It generally began 2 months after surgery. (Table 3 )

Two patients (6 .4\%) with FIGO stage IIIC had suboptimal radical surgery with residual disease. Therefore, they received second look surgery after adjuvant chemotherapy.

The first one had six curses of VAB without residual tumor. She underwent second look surgery consisting on total hysterectomy.

The second one had six curses of VAB with residual disease. Total hysterectomy with tumoral resection was performed as second look surgery.

Residual disease after completion of treatment was noted in three patients (9.6\%): 2 of them were classified as stage IIIC and the third one as stage IC. Initial treatment was radical surgery for the first two patients with residual tumor in both cases, one of them received adjuvant 
chemotherapy and the other one had adjuvant radiotherapy. The patient with FIGO stage IC had conservative surgery without residual tumor than adjuvant chemotherapy was performed. Second line treatment was chemotherapy performed in the two patients.

Table 3: Dose and irradiation field according to FIGO stage.

\begin{tabular}{|lllll|} 
Case & FIGO & Type of surgery & Irradiation field & \multicolumn{1}{c|}{$\begin{array}{l}\text { Dose of } \\
\text { radiotherapy } \\
\text { (Gy) }\end{array}$} \\
$\mathbf{1}$ & IIIC & $\begin{array}{l}\text { Conservative } \\
\text { +mesenteric lymphnode biopsy }\end{array}$ & $\begin{array}{l}\text { Abdominopelvic+mediastinal } \\
\text { + supra clavicular }\end{array}$ & $30+20$ \\
\hline $\mathbf{2}$ & IIIC & Radical & $\begin{array}{l}\text { Abdominopelvic+ iliac and lateroaortic } \\
\text { lymphnodes }\end{array}$ & $20+35$ \\
\hline $\mathbf{3}$ & IIA & $\begin{array}{l}\text { Radical+ lateroaortic lymphnode } \\
\text { biopsy (-) }\end{array}$ & $\begin{array}{l}\text { Abdominopelvic+ iliac and lateroaortic } \\
\text { lymphnodes }\end{array}$ & $30+20$ \\
\hline $\mathbf{4}$ & IA & Radical & Iliac and lateroaortic lymphnodes & 30 \\
\hline $\mathbf{5}$ & IA & Conservative & Abdominopelvic & 20 \\
\hline $\mathbf{6}$ & IIIC & $\begin{array}{l}\text { Conservative+ lateroaortic } \\
\text { lymphnode biopsy(+) }\end{array}$ & $\begin{array}{l}\text { Iliac+ lateroaortic lymphnodes+ } \\
\text { supraclavicular+mediastinal }\end{array}$ & $40+16$ \\
\hline $\mathbf{7}$ & IIIC & $\begin{array}{l}\text { Conservative+ lateroaortic } \\
\text { lymphnode biopsy(+) }\end{array}$ & Abdominopelvic & 30 \\
\hline $\mathbf{8}$ & IA & Conservative & Iliac and lateroaortic lymphnodes & 25 \\
\hline $\mathbf{9}$ & IIIC & Conservative & Iliac and lateroaortic lymphnodes & 50 \\
\hline $\mathbf{1 0}$ & IC & Conservative & Abdominopelvic & 36 \\
\hline
\end{tabular}

Table 4: Site and management of recurrences.

\begin{tabular}{|lllllllll} 
Cases & $\begin{array}{l}\text { FIGO } \\
\text { stage }\end{array}$ & $\begin{array}{l}\text { Type of } \\
\text { surgery }\end{array}$ & $\begin{array}{l}\text { Residua } \\
\text { l tumor }\end{array}$ & $\begin{array}{l}\text { Chemothe } \\
\text { rapy (CT) }\end{array}$ & $\begin{array}{l}\text { Radiotherap } \\
\mathbf{y}(\mathbf{R T})\end{array}$ & $\begin{array}{l}\text { Time of } \\
\text { recurrence }\end{array}$ & Site & $\begin{array}{l}2^{\text {nd }} \text { line } \\
\text { treatment }\end{array}$ \\
\hline $\mathbf{1}$ & IA & $\begin{array}{l}\text { Conservat } \\
\text { ive }\end{array}$ & 0 & 0 & 0 & 18 months & $\begin{array}{l}\text { Abdomino } \\
\text {-pelvic }\end{array}$ & $\begin{array}{l}\text { adominopelv+ } \\
\text { supraclav+me } \\
\text { diastinal }\end{array}$ \\
\hline $\mathbf{2}$ & IIIB & Radical & 0 & + & 0 & 12 & Pelvic & CT : VIP \\
\hline
\end{tabular}

Two recurrences were noted $(6.4 \%)$ and it occurred within 20 months of diagnosis. Their FIGO stage was IA and IIIB. These two patients relapsed in the pelvis or the abdomen and their management was either chemotherapy or radiotherapy (Table 4$)$.

Two patients presented distant metastases within 12 months of diagnosis. FIGO stage was IA for one of them and IC for the second one. Initial treatment consisting on optimal conservative surgery without residual disease was performed in two patients and one of them received adjuvant chemotherapy.

The first patient presented distant metastases in the mediastinum and supraclavicular lymph nodes. She received radiotherapy with a total dose of 48Gy in the abdominopelvic area and the metastatic site.

Metastatic spleen was noted in the second patient. Second line treatment was splenectomy with chemotherapy.
Median follow-up was 57 months (ranged from 1 to 256 months). 26 patients ( $83.9 \%$ ) were free of disease with a follow up that ranged from 7 to 182 months.

The patients who presented recurrences were free of disease after a median follow up period of 119 months. Among the patients who still have residual disease after treatment: one of them died at 12 months after surgery and radiotherapy.

The second patient had second line surgery consisting on hysterectomy with tumor reduction and chemotherapy. Complete remission was noted after a follow-up period of 104 months.

The third one had a second line chemotherapy.

Among distant metastatic cases, the patient who had metastatic supraclavicular lymph nodes respond well to chemo and radiotherapy. She was free of disease at 73 
months after treatment completion. The other one who had metastatic spleen died 6 months after surgery.

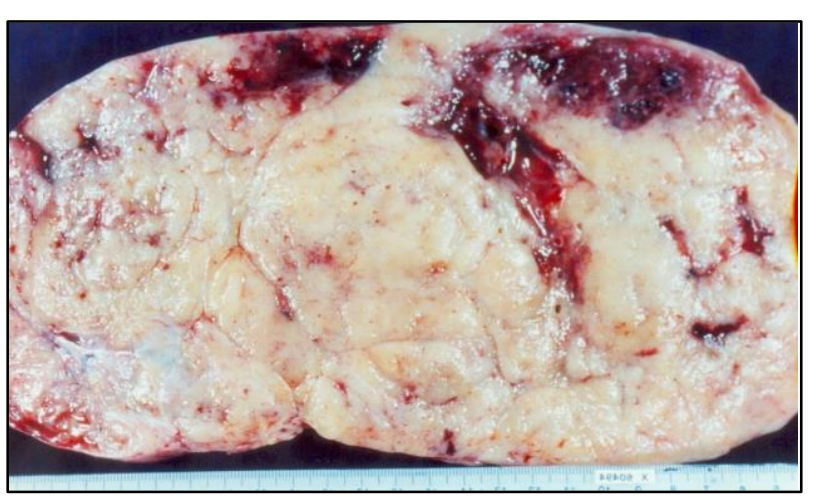

Figure 1: Dysgerminoma- lobulated and whitish macroscopic appearance.

Therefore, we noted four deaths including 3 deaths related to the disease.

Five years and ten years overall survival rate was $89.4 \%$. Neither age nor tumor size or type of surgery was significantly associated with overall survival. Although, FIGO stage and residual tumor after surgery were significantly associated with overall survival at 5 years and 10 years.

Five years event free survival rate was $85.2 \%$, and the ten years one was $66.3 \%$. It was significantly different when associated with residual tumor after surgery but age, FIGO stage, type of surgery and tumor size had no impact on event free survival.

\section{DISCUSSION}

Ovarian Dysgerminomas are malignant germ cell tumors that affects mostly children and young women. ${ }^{5}$ In our series, the median age of patients was 22 years old and $76.6 \%$ of them were less than 30 years old. These tumors are histologically equivalent to testicular seminoma due to their origin. The most common clinical presentation is a young woman with a subacute lower quadrant pain and a pelvic mass found by physical examination. ${ }^{6}$ In fact, our series illustrate 31 cases of dysgerminomas with abdominal distention as the most common symptom of nearly $42 \%$ of cases.

Diagnosis can be made by pelvic ultrasound imaging which found in $59 \%$ of cases a highly vascularized, large, solid, lobulated adnexel mass with irregular internal echogenicity. ${ }^{6}$ In addition, pelvic MRI can be suggested to confirm the diagnosis: it showed typically a multilobulated solid mass with lobules divided by fibrovascular septa. ${ }^{6}$ However, the final diagnosis of dysgerminoma is confirmed by anatomopathological study on surgical specimen. In our cases, ultrasound examination was the reliable imaging technique and MRI was not made for any patient. Tumor markers may help to establish the diagnosis but they are especially a tool for postoperative monitoring to detect any recurrence. Diagnosis is established generally at an early stage with disease limited to one ovary, which suggest a good prognosis. Indeed, in the literature, $70 \%$ of dygerminomas were stage $\mathrm{I}$ at the time of diagnosis and only $10 \%$ involved both ovaries. ${ }^{7}$

The standard treatment of ovarian dysgerminomas is surgery with or without adjuvant treatment. Traditionally, Full staging procedure including hysterectomy with bilateral salpingoophorectomy, omentectomy, appendicectomy and pelvic and lateroaortic lymphadenectomy was recommended for advanced stage even in young nulliparous patients. ${ }^{3}$ Considering the young age of the majority of patients, fertility, shoud be taken into consideration to make therapeutic strategies. Currently, all authors in the literature agree on the indication of fertilty-sparing surgery to treat early stage ovarian dygerminomas or even advanced stage dysgerminomas in women wishing to retain their reproductive potential. ${ }^{4}$ So that, extensive complete staging surgery should be avoided. In fact, conservative surgery consist on unilateral salpingoophorectomy with staging biopsies and preseving of the uterus and contralateral ovary but opinions varie on whether a biopsy should be done despite a normal appearance of the contralateral ovary. ${ }^{6}$ In our series, $67.7 \%$ of patients underwent fertility-sparing surgery and 4 of them (19\%) underwent contralateral ovarian biopsy that was negative in all cases. It didn't show any occult disease. There is evidence showing that conservative surgery for stage IA dysgerminoma is safe with a 10-year survival rate of $91 \%$ in the prechemotherapy era. ${ }^{3}$ However, radical surgery still recommended only for old patients, dysgerminomas affecting both ovaries and dysgenesic gonads. ${ }^{8}$

Adjuvant treatment for stage I ovarian dysgerminomas include radiotherapy, chemotherapy or clinical, radiological and biological surveillance. There is no randomised trial, which studied these options. According to Sagaes et al postoperative abstention is conceivable only for stage IA. However, stage IB and IC require adjvant chemotherapy. ${ }^{9}$

Prophylactic radiotherapy of pelvic and lateroaortic lymphnodes for stage IA and IB dysgerminomas tend to vanish in favor of simple surveillance.

For advanced stage of dysgerminomas, chemotherapy is as effective as radiotherapy with less side effects.

The chemosensitivity of ovarian dysgerminomas has revolutionized their management and prognostic. ${ }^{4}$ In fact, Bleomycin-etoposide-cisplatine (BEP) is the first line chemotherapy with treatment every 3 weeks for 3 or 4 courses. ${ }^{3}$ Despite that, chemotherapy can have significant long-term side effects, but it spares fertility and keeps the possibility of a later pregnancy. ${ }^{3}$ 
Adjuvant chemotherapy after conservative treatment was recommended for stage IC, stage II and stage III dysgerminomas with 2 or 3 courses if residual tumor was noted and 4 courses if surgery was complete R0. For stage IV, 4 courses of BEP was indicated. ${ }^{10}$ In our series, 15 patients $(48.3 \%)$ received adjuvant chemotherapy. Among them, 5 cases were at stage IA, chemotherapy was indicated because tumor size was high in 4 cases and surgery was non optimum with residual tumor in one case. For 2 patients classified as stage IIIC, chemotherapy was not BEP regimen. It was VAB-6: Cyclophosphamide, vinblastine, bleomycin, dactinomycin, and cisplatin.

Chemotherapy is also indicated for recurrent or metastatic disease.

Whatever the stage of the tumor, dysgerminoma can recur. Recurrence rate after conservative treatment varied between 17 and $32 \%$ in the literature. ${ }^{11,12}$ In our study, the recurrence rate after conservative treatment was $5 \%$. Alwin et al suggested a close follow up after conservative treatment because 15 to $25 \%$ of cases relapsed within two years of surgery. ${ }^{13}$ Late recurrence over 2 years has been reported as a very rare phenomenon. ${ }^{3}$ In our study, there was only 2 recurrences that occurred below 2 years from surgery. These recurrences were classified as stage IA and IIIB. They responded well to chemotherapy and radiotherapy and they remained disease free.

The spread of dysgerminoma is often locoregional to the contralateral ovary, the pelvis or mediastinal, supraclavicular or retroperitonal lymphnodes. ${ }^{14}$ However, distant metastasis are uncommon and the most common site is liver in $90 \%$ of cases, followed by lung, bone and brain. ${ }^{15}$ In our series, 2 patients developed distant metastasis: the first patient was stage IA dysgerminoma that developed supraclavicular and mediastinal metastasis within 14 months of surgery and it respond well to radio and chemotherapy, the second case was stage IC dysgerminoma which presented splenic metastasis within 10 months of surgery. She had splenectomy with chemotherapy and she died after 6 months.

\section{CONCLUSION}

Ovarian dysgerminomas are an uncommon disease that has a good prognosis. Its management is essentially surgical consisting on fertility sparing surgery that preserves the reproductive function. It relapses more often within 2 years of surgery and late recurrence over 2 years are rare. Considering their chemosensitivity, recurrences are salvageable but late side effects should be taken into account especially that patients are young.
Funding: No funding sources

Conflict of interest: None declared

Ethical approval: Not required

\section{REFERENCES}

1. Chen Y, Luo Y, Han C, Tian W, Yang W, Wang Y et al. Ovarian dysgerminoma in pregnancy: A case report and literature review. Cancer biology \& therapy. 2018;19(8):649-58.

2. Krepart G, Smith J, Ruteldge F, Delclos L. The treatment for Dysgerminoma of the ovary. Cancer. 1978;41:986990.

3. Vicus D, Beiner ME, Klachook S, Le WL, Laframboise S, Mackay H. Pure Dysgerminoma of the ovary 35 years on: A single institutional experience. Gynecologic Oncology. $2010 ; 117: 23-6$.

4. Nasioudis D, Frey MK, Chapman-Davis E, Caputo TA, Holcomb K. Fertility-preserving surgery for advanced stage ovarian germ cells tumors. Gynecologic Oncology. 2017;147:493-6.

5. Newton C, Murali K, Ahmad A, Hockings H, Graham R, Liberale Vet al. Multicentre retrospective cohort study of ovarian germ cell tumours : Evidence of chemotherapy de-escalation and alignement of paediatric and adult practice. European Journal of Cancer. $2019 ; 113$ :19-27.

6. Michael K, Wampler K, Underwood J, Hansen C. Ovarian Dysgerminoma: A case study. Journal of Diagnostic Medical Sonography. 2015 ;31(5):327-30.

7. Gallion H, Van nagell J, Donaldson E, Powell D. Ovarian Dysgerminoma : Report of seven cases and review of literature. Am J Obstet Gynecol. 1988;158:591-5.

8. Fishman Da, Schwartz Pe. Current approaches to diagnosis and treatment of ovarian germ cell malignancies. Curr Opin in Obstet Gynecol. 1994;6:98104.

9. Sagae S, Kudo R. Surgery for germ cell tumors. Semin Surg Oncol. 2000;19:76-81.

10. Observatoire des Tumeurs Malignes Rares Gynécologiques. http://www.ovaire-rare.org/ Référentiel -version mars. 2017. Accessed on $10^{\text {th }}$ May, 2021.

11. Gershenson DM, Morris M, Cangir A, Kavanagh JJ, Stringer CA, Edwards CL. Treatment of malignant germ cell tumors of the ovary with bleomycin, etoposide and cisplatin (BEP). J Clin Oncol. 1990;8:715-20.

12. Asadourian LA, Taylor MB. Dysgerminoma an analysis of 105 cases. Obstet Gynecol. 1969;33:370-3.

13. Alwin J, Rene C, Alexander H. Late recurrence in ovarian dysgerminoma with successful response to standard adjuvant chemotherapy: a case report and review of the literature. Gynecol Obstet. 2001;81:314-7.

14. Talerman A. Germ cell tumors of the ovary in blaustein's pathology of the female genital tract. 4th ed. New York; Springer-verlag. 1995; 15:860-74.

15. Dubrex. Histopathologie Gynécologique. 2ème éd. Paris: Masson. 1982;12:378-406.

Cite this article as: Salhi H, Ayadi MA, Bouraoui I, Chargui R, Rahal K. Pure dysgerminoma of the ovary: a study of 31 cases. Int J Reprod Contracept Obstet Gynecol 2021;10:3197-203. 